\title{
Fenomena Judi Tajen Dan Upacara Yadnya Dalam Penciptaan Karya Seni Rupa
}

\author{
I Wayan Suardana ${ }^{1}$, I Ketut Suteja ${ }^{2}$, Ni Kadek Karuni ${ }^{3}$
}

Program Studi Kriya Seni, Fakultas Seni Rupa dan Disain ISI Denpasar

suar.tulu63@gmail.com

\begin{abstract}
Bagi masyarakat Hindu, melaksanakan upacara yadnya merupakan bagaian yang tak terpisahkan, baik yang berhubungan dengan pelaksanaan upacara atas nama pribadi, kelompok dadya, maupun desa pakraman. Masyarakat melaksanakan upacara dengan perasaan tulus iklas, murni dan suci sebagai ucapan terimakasih pada Yang Kuasa atas segala rahmatNYA. Suatu hal yang sangat memprihatinkan adalah pelaksanaan upacara yang murni, suci, tulus iklas, dengan tampilan yang sangat artistik, tidak selalu diikuti dengan suasana religius karena upacara tersebut sering dimanfaatkan untuk menunjukan stratifikasi kehidupan sosial di masyarakat, sehingga sering dalam ritual seremonial lebih utama dari religiusnya. Selain itu banyak ritual selalu dibarengi dengan judi tajen yang dimaknai sebagai tabuh rah. Sebuah fenomena, antara ritual yang suci selalu bergandengan dengan gengsi dan judi yang maksiat. Hal ini disebabkan karena pemahaman masyarakat tentang upacara yadnya, tabuh rah dan tajen sangat kurang. Upacara pun tak terhindar dari situasi paradoksal, berada dalam suatu posisi yang sangat sulit, karena upacara yang sangat religius selalu dibarengi dengan gengsi dan judi yang maksiat. Tujuan penciptaan ini adalah untuk memberi pemahaman pada masyarakat bahwa upacara yadnya harus dilaksanakan dengan hati yang tulus iklas dan tidak boleh diikuti dengan judi. Metode yang digunakan adalah: eksplorasi, improvisasi, dan perwujudan. Hasil penciptaan ini diharapkan dapat dijadikan studi komparatif bagi seniman dan mahasiswa dalam penciptaan karya seni lebih lanjut.
\end{abstract}

Kata Kunci: Fenomena, Upacara Yadnya, dan Judi Tajen.

\section{The Phenomenom of Tajen Gambling and Hindu Rituals In the Works of Art}

Religious ceremonies are inseparable part of being Balinese Hindus, either those related to personal yadnya rites, dadya groups, or desa pakraman. Various ritual facilities are attractively and beautifully displayed, expressing the beauty of those offerings as well as sincere, pure and sacred feeling. What concerns us most is that the supposedly sacred rituals that are held with sincere and pure feelings are not always meant to be purely religious activities. It could be because such rituals are held to show off social status; therefore ceremonial aspects are more dominant than the religious ones. In fact, more often than not, tajen cockfights accompany the rituals construed as tabuh rah: a phenomenon that combines sacred rituals with a show off and immoral gambling. The reason has been the lack in understanding of the rituals: tabuh rah and tajen. Here lies a difficult paradox: the sacred religious rites have always been accompanied by a show off and immoral cockfight as gambling. The creation of this sculpture work is intended to give bettors (or bobotohs) an understanding that the rituals should be held with sincerity and not using them for gambling. The methods which are used, such as: exsploration, improvisation, and manifestation. The creation is expected to serve the purpose of comparative studies on further creation sculptural works.

Keywords: phenomenon, Yadnya, tajen gambling.

Proses Review : 1 - 31 Maret 2018, Dinyatakan Lolos: 10 April 2018 


\section{PENDAHULUAN}

Upacara merupakan ritual dalam agama Hindu yang sering disebut dengan yadnya yaitu korban suci yang dipersembahkan sebagai rasa sujud bhakti kepada Yang Maha Kuasa. Yadnya mencakup segala aspek kehidupan, sebagai aspek etika, moral, dan spiritual. Yadnya adalah pelayanan yang tulus iklas kepada sesama umat manusia dan makhluk hidup lainnya untuk kesejahtraan dunia. Yadnya dapat pula diartikan memuja, menghormati, berkorban, mengabdi, berbuat kebajikan, pemberian dan penyerahan yang tulus iklas demi kesejahtraan dan kesempurnaan hidup bersama. (Subawa, 2012: 9).

Sudah menjadi kewajiban bagi seluruh umat Hindu untuk mempersembahkan yadnya setiap hari, baik dalam skala kecil (nista), sedang (madya), dan besar (utama) yang berlandaskan pada srada yaitu keyakinan penuh apa yang akan dipersembahkan, lascarya yaitu ketulus iklasan yang mendalam, tanpa pamerih, dan sastra yaitu sesuai dengan sastra dan agama, sehingga yadnya yang dilaksanakan menjadi bermakna.

Bhuta Yadnya adalah salah satu upacara dalam Agama Hindu yang bermakna sebagai korban suci yang tulus iklas kepada para bhuta kala untuk memelihara kesejahteraan alam semesta. Dalam upacara bhuta yadnya biasanya juga diadakan sabung ayam sebagai persembahan darah pada para bhuta kala yang disebut dengan Tabuh Rah. Tabuh rah dimaknai sebagai penaburan darah binatang ke tanah (pertiwi) yang bertujuan untuk membersihkan alam beserta isinya, sehingga alam menjadi seimbang dan harmonis.

Konsep yadnya ini jarang dipahami secara mendalam oleh masyarakat, sehingga banyak pelaksanaannya karena " $G u$ gon Tuwon" yaitu mengikuti tradisi yang telah berjalan, dan sama sekali tidak memahami makna dan fungsinya. Kurangnya pemahaman masyarakat pada konsep yadn$y a$, sehingga tidak jarang pelaksanaan yadnya sangat jauh menyimpang dari esensi dasar sebagai persembahan yang tulus iklas untuk mendapatkan anugrah dan pahala. Pada tataran individu banyak yadnya dilakukan untuk menunjukan stratifikasi kedudukan sosial di masyarakat, sehingga penampilan menjadi bagaian yang paling penting dan utama dengan mengesampingkan segi religiusnya. Pelaksanaan yadnya lebih menonjolkan seremonial dari pada nilai religiusnya dengan garapan dekorasi yang sangat prestisius. Suatu yang tidak bisa dihindari, bahwa dalam yadnya aktivitas "Keteben" jauh lebih besar dari pada "Keluan" (Seremonial jauh lebih besar dari pada ritual).

Suatu hal yang sangat memprihatinkan adalah setiap pelaksanaan yadnya selalu diikuti dengan rentetan judi, baik itu dikaitkan dengan yadnya itu sendiri maupun judi sebagai hiburan. Ada beberapa rentetan yadnya yang memerlukan tetesan darah untuk tetabuhan. Tetesan darah ini sering dilaksanakan dengan sabung ayam dalam bentuk tajen yang dimaknai sebagi tabuh rah, pada hal keduanya memiliki fungsi dan makna yang berbeda. Masyarakat menganggap bahwa tajen sama dengan tabuh rah dan merupakan rangkaian yadnya yang harus dilaksanakan. Pemahaman yang salah ini mengakibatkan pelaksanaan yadnya tidak terhindar dari perjudian, dan telah berlangsung lama, sehingga dianggap budaya tradisi yang perlu dilestarikan.

Fenomena ini merupakan sebuah paradoks dalam kehidupan beragama Hindu masyarakat Bali. Agama pun tak terhindar dari situasi paradoksal, berada dalam suatu posisi yang sangat sulit, karena di sana ada keluhuran dan juga ada kebusukan yang begitu kabur batasnya (Sugiharto, 2000: 255). Terdapat berbagai penyimpangan dalam pelaksanaan ritual agama, namun telah dilakukan secara berkesinambungan sehingga menjadi tradisi yang sangat kuat. Masyarakat selalu memberi jawaban "Anak mula keto uling nguni" (memang begitu adanya dari dulu) (Kerepun, 2005: 60).

Menyimak dari kenyataan ini, sebagai seorang intelektual dan pencipta karya seni merasa sangat khawatir, prihatin dan tertantang dengan situasi dan kondisi masyarakat Bali yang penuh dengan fenomena di balik hingar-bingarnya pariwisata. Dari kekhawatiran dan keprihatinan perasaan pencipta menjadi shok, khaos,agoni, dan tertantang untuk melahirkan sesuatu karya agar dapat berguna bagi masyarakat. Sebagai seniman intelektual, pencipta berkeinginan untuk memvisualkan fenomena sosial ritual dan judi tajen dalam sebuah karya rupa yang unik dan artistik. Karya ini akan lebih mengarah pada kritik sosial dan pesan moral pada masyarakat bebotoh untuk tidak mengotori taksu Bali. Aktivitas ritual adat dan agama Bali yang ada harus dikembalikan pada makna dan fungsinya. Kemurnian dan kesucian ritual harus dipertahankan, jangan sebaliknya dijadikan tameng untuk menyelenggarakan judi tajen.

\section{KAJIAN RITUAL}

Dalam sejarah peradaban Veda banyak jenis ritual sakral yang digelar. Ritual adalah mediasi kontemporer untuk melenyapkan kejenuhan menuju pemahaman terhadap kesempurnaan jati diri. Ritual adalah tahap kesadaran awal yang sepatutnya membawa kesadaran yang lebih tinggi yaitu kesadaran spiritual (Daksa, 2008: 4).

Agama Hindu yang ada di Bali, pada kenyataannya lebih diwarnai dengan pelaksanaan agama melalui jalan bhakti dan kharma, sehingga dalam realitasnya lebih menekankan pada bentuk ritus yang simbolik. Pada dasarnya ritus di Bali dapat dilihat secara vertikal dan horizontal. Secara vertikal seluruh ritus selalu dikaitkan dengan ritus kepentingan alam bawah (alam butha), alam tengah (alam manusia), dan alam atas (alam Dewa). Secara horizontal keane- 
karagaman ritus dapat dipahami dari ritus tingkat keluarga terutama dalam kaitannya dengan ritus stages slong the life cycle (Triguna, 1994: 74).

Inti sari seluk beluk perilaku ritualistik agama Hindu secara makro diatur dalam kitab "Kalpa", yang secara menyeluruh memiliki dasar yang sama yaitu Atmanastuti yaitu dilakukan dengan tulus iklas tanpa pamerih (Djendra, 2013: 62). Ritual merupakan pengejawantahan dari hakekat kerja sebagai manusia yang beragama, dan ritual adalah wahana untuk meningkatkan solidaritas sosial antar umat yang dimaknai sebagai tingginya itensitas untuk bertemu secara berulang, yaitu solidaritas akan terwujud bilamana antara warga masyarakat terjadi kontraksi sosial melalui ritus-ritus yang ada dalam sistem agama (Triguna, 1994: 76).

Ritual dalam agama Hindu sering disebut dengan upacara atau yadnya. Upacara terdiri dari dua suku kata yaitu "Upa" dan "Cara", Upa artinya dekat atau mendekat, dan Cara berarti harmonis, seimbang, dan selaras. Upacara memiliki makna dengan keseimbangan, keharmonisan, dan keselarasan dalam diri, kita mendekatkan diri dengan Tuhan Yang Maha Esa (Wijayananda, 2004: 49).

Yadnya diartikan sebagai pemujaan, persembahan, dan kurban suci. Yadnya juga sebagai perbuatan yang dilakukan dengan ketulus iklasan dan kesadaran sebagai persembahan pada Tuhan. Pada intinya unsur-unsur yadnya adalah perbuatan, ketulusiklasan, kesadaran, dan persembahan. Memelihara lingkungan alam, mengendalikan hawa napsu, mengasihi sesama makhluk, mengentaskan kemiskinan, menolong orang kesusahan juga dapat digolongkan sebagai yadnya. Yadnya tidak sebatas upacara saja, kerja keras dan ketulus iklasan dalam melaksanakan upacara, itulah sesuangguhnya yadnya (Wijayananda, 2004: 15).

\section{KAJIAN TAJEN}

Istilah tajen berasal dari kata "taji" yang artinya susuk pada kaki ayam yang memiliki pengertian tajam dan " $t a$ jip" dalam bahasa Bali. Pengertian tajam ditekankan pada taji atau senjata yang digunakan ayam dalam beradu, sebab hanya ayam yang diadu sajalah yang menggunakan taji. Tajen berarti sabungan ayam yang sering juga disebut dengan "kelecan" (Mertha, 2010: 11)

Kata tajen berasal dari kata taji yang artinya tajem, landep, atau runcing yaitu susuh pada kaki ayam. Dari kata taji ini kemudian berkembang menjadi tajen. Kata tajen kadangkala didwipurwakan menjadi tetajen (Suada, 2013: 85).

Tajen telah dikenal oleh masyarakat Bali sejak Bali kuno, yang penyelenggaraannya secara tekstual berkaitan dengan ritual yang disebut dengan Tabuh Rah (Atmadja, 2010: 129). Kata “Tabuh Rah” merupakan kata mejemuk yaitu rangkaian dua buah kata menjadi satu pengertian. Adapun kata dasarnya adalah "tabuh" dan "rah". Secara etimologis kata tabuh berasal dari kata "tawur" yang berarti "bayar". Kata "tawur" berubah menjadi "tabur", dan kata "tabur" akhirnya berubah menjadi "tabuh". Kata "rah" berasal dari kata "darah". Kata "tabuh rah" berarti "tawur darah" yaitu pembayaran dengan darah (Purwita, 1978: 1).

Tabuh rah dalam hubungannya dengan upacara di Bali berpangkal pada suatu bentuk upacara kurban yang ada kaitannya dengan kekuatan para roh leluhur dengan kekuatan gaib. Setiap kurban selalu diikuti dengan darah atau tabuh rah yang bermakna untuk menebus dosa atau demi eratnya hubungan manusia dengan dunia gaib atau roh-roh. Sementara itu juga untuk merasakan kegembiraan demi eratnya persahabatan antara sesama manusia agar jangan ditempa oleh suatu malapetaka dan darah itu mengandung kekuatan magis (Utarayana, 1993: 12-13).

\section{FENOMENA UPACARA DAN JUDI TAJEN}

Aktivitas adat dan agama di Bali sangat sulit untuk dipisahkan, selalu menyatu beriringan satu dengan yang lainnya. Upacara yadnya merupakan aktivitas agama, tetapi dalam proses persiapannya merupakan aktivitas adat. Untuk melaksanakan upacara yadnya harus didukung oleh aktivitas adat. Menyatunya aktivitas ini terkadang menyebabkan pelaksanaan upacara menjadi besar dan menghabiskan biaya yang cukup banyak. Kewajiban adat sering terlalu berlebihan, tidak efektif dan efisien, tetapi umat tidak berani mengurangi karena takut kena sangsi moral dari masyarakat.

Adanya aktivitas adat dalam upacara memberi peluang pada umat untuk menunjukan gengsinya pada masyarakat lainnya, sehingga upacara tidak menjadi murni dan suci, karena tidak dibarengi dengan perasaan hati yang tulus. Upacara yadnya yang mereka lakukan harus mewah dan meriah untuk menunjukan dirinya sebagai seorang yang kaya dan berwibawa. Budaya adat sering menuntun aktivitas upacara menjadi rumit dan sangat sulit untuk disederhanakan.

Menjadi sebuah kesalahan budaya yang berkesinambungan, keberhasilan pelaksanaan upacara yadnya sering dinilai dari kesuksesan dalam melakukan aktivitas adat. Untuk melaksanakan sebuah upacara yadnya umat akan selalu berusaha untuk memberi pelayanan yang baik pada masyarakat agar proses upacara tidak cacat. Loyaritas umat dalam melayani masyarakat adat menjadi ukuran utama dalam peneliaian keberhasilan pelaksanaan upacara yadnya. Budaya ini sering menjadi ajang pemborosan yang tidak karuan untuk menghindari upacara yadnya tidak cacat.

Pelaksanaan upacara agama yang lebih menonjol adalah hal-hal yang bersifat adat dan budaya, sehingga nilai kea- 
gamaan makin kabur. Dengan rancunya antara adat dan agama, maka sangat sulit untuk memedakan mana yang sesungguhnya agama dan mana yang sesungguhnya adat budaya. Upacara agama sering divonis rumit, sulit, dan mahal, namun sesungguhnya yang rumit, sulit dan mahal adalah adat budaya yang sering mendominasi prosesi upacara agama (Subawa, 2012: 37).

Selain rancunya antara adat dan agama, setiap pelaksanaan upacara yadnya selalu diikuti dengan rentetan judi dan dianggap sebagai budaya yang wajar. Pelaksanaan Upacara yadnya dianggap kurang sukses apabila tidak dibarengi dengan judi karena suasananya sangat sepi. Suasana kemeriahan sering dijadikan tolok ukur kesuksesan upacara yadnya dan bukan pada inti sari pelaksanaannya. Suatu yang sangat ironis, di balik kesucian upacara yadnya selalu terselip perjudian, baik yang dilaksanakan dengan sengaja untuk mencari dana, atau mencari hiburan. Sebuah kekeliruan yang sangat mendasar dan berkepanjang telah merasuk masuk pada pemahaman masyarakat yang sangat sulit diluruskan menuju yang benar. Gejala ini menunjukan seakan judi itu bermasyarakat sebagai sebuah budaya yang wajar yang tidak melanggar ajaran agama dan bebas hukum.

Judi tajen dalam upacara yadnya tidak berdiri sendiri, tetapi diikuti oleh judi-jidi lainnya yang sama sekali tidak ada kaitannya dengan ritual seperti capdeki, ceki, main dadu, dan blokkiu. Judi ini total untuk mencari kesenangan, yang dilakukan sebelum atau sesudah sembahyang, pesertanya tidak saja orang dewasa, tetapi juga banyak anak-anak yang ikut berjudi. Pura dimanfaatkan sebagai ajang untuk bermain judi, sebagai tempat untuk mencari hiburan karena dianggap aman dan nyaman.

\section{REFORMASI UPACARA YADNYA}

Sesungguhnya agama Hindu adalah agama yang sangat mudah dilaksanakan, karena dalam agama Hindu tidak ada suatu keharusan, yang terpenting umatnya dapat menjalankan dengan tatanan etika yang benar. Laksanakan upacara yadnya sesuai dengan kemampuan berdasarkan sastra yang ada, jangan berlebihan, apalagi karena hanya mengikuti tetangga. Lakukan upacara yadnya dengan konsep Atmanastuti yaitu sesuai dengan hati nurani sendiri dengan tidak lepas dari filosofi dan etika ritual itu sendiri (Subawa, 2012: 21).

Adanya tukang banten yang kurang memahami secara mendalam hakiki dari benten, sering menambahkan elemen banten pada acara upacara tertentu, sehingga upacara selalu berkembang terutama bentuk dan penampilannya. Adanya kreasi ini menyebabkan munculnya perbedaan sarana dan bentuk upacara yadnya antara banjar yang satu dengan banjar yang lainnya, pada hal makna dan fungsinya sama. Kreasi dan ekspresi tukang banten untuk mengembangkan variasi tampilan tidaklah salah, tetapi hakekat, makna, dan fungsinya jangan dirubah. Kreasi dan ekspresi tukang banten yang berlebihan terkadang menyebabkan upacara menjadi mewah dan mahal.

Adanya fenomena ini perlu diadakan reformasi upacara untuk kembali pada hakiki ritual yang sejatinya dengan mengutamakan konsep filosofi dan bukan pada seremonial penampilan. Reformasi dalam hal ini bukan menghilangkan konsep dasar dari sastra agama, tetapi meluruskan pada tataran yang benar dan sesuai dengan fungsi dan tujuan yang sesungguhnya. Reformasi juga perlu dilakukan pada penyederhanaan bentuk dan tampilan sehingga upacara tidak terbebani dengan biaya yang tinggi dan proses pembuatan yang lama.

Reformasi besar yang juga perlu dilakukan dalam upacara yadnya adalah pelaksanaannya tidak boleh diikuti dengan bentuk judi apapun. Upacara harus dijauhkan dari sabung ayam dengan alasan tabuh rah, dan metetabuhan sebaiknya dilakukan dengan menyembelih ayam. Upacara yadnya jangan dimanfaatkan untuk bermain judi hanya karena untuk mencari kesenangan. Pelaksanaan upacara tidak harus dilaksanakan dengan hati senang dan gembira, tetapi dengan hati yang tulus iklas tanpa pamerih. Berjudi di tempat upacara merupakan perbuatan yang bersalah karena mengotori upacara itu sendiri. Kebiasaan masyarakat berjudi saat upacara harus direformasi, dihilangkan sama sekali, sehingga pelaksanaan upacara menjadi khusuk dan khidmat. Para yajamana tidak boleh melakukan penggalian dana untuk acara upacara dengan melkaksanakan judi tajen. Dana yang didapat dari hasil berjudi adalah dana kotor yang tidak pantas digunakan untuk menyelenggarakan upacara yadnya.

\section{TRANSFORMASI RITUAL DAN JUDI TAJEN DALAM KARYA RUPA}

Banyak elemen estetis yang dapat dilihat dalam pelaksanaan ritual, baik dalam bentuk fisik maupun proses pelaksanaannya. Secara visual elemen estetis itu dapat dilihat dari berbagai bentuk sarana ritual yang sangat unik dan menarik dengan tampilan yang sangat indah. Sesajen dan sarana lainnya merupakan karya seni yang memiliki nilai estetika yang sangat tinggi dan dapat menggugah ekspresi untuk menciptakan suatu karya seni baru yang lebih inovatif.

Selain sarana upacara, prosesi upacara juga merupakan momen estestis yang sangat unik untuk ditransformasikan menjadi karya seni yang bernilai tinggi. Kebersamaan masyarakat bergotong royong dalam menyiapkan sarana upacara, baik lelaki maupum perempuan dengan segala gerak-gerik dan tingkah lakunya merupakan objek yang sangat apik untuk dituangkan menjadi karya seni. Dengan imajinasi yang dalam, segala momen estetik diolah sedemikian rupa menjadi ciptaan karya seni dengan identitas garapan yang sangat kuat. Dengan meramu berbagai objek 
estetik yang ada akan melahirkan sebuah ciptaan original sebagai curahan emosional yang khas dan karakteristik.

Kekayaan sumber ide yang ada ditranformasikan dalam karya rupa dan dikembangkan dengan gagasan inovatif pada berbagai media rupa, baik dalam bentuk dua maupun tiga dimensi. Elemen-elemen estetis yang telah tersedia diolah dengan interpretasi pencipta, sehingga menjadi karya yang unik dan menarik. Perwujudan karya tidak semata memiliki nilai estetika, tetapi juga sarat akan makna yang terkandung di dalamnya terutama beberapa penyimpangan yang telah menjadi tradisi dan berkesinambungan.

Dalam penciptaan karya ini tema upacara yadnya dan judi tajen diolah sedemikian rupa menjadi sebuah karya yang berbeda dengan yang telah ada, yang pada intinya karya merepresentasikan fenomena upacara dan judi tajen yang berdampak pada kehidupan budaya masyarakat yang lebih memperlihatkan kemewahan daripada nilai sakralnya. Penampilan menjadi lebih utama dari pada hakekat upacara itu sendiri. Secara visual wujud karya yang diciptakan merupakan metafora fenomena upacara dan judi tajen itu sendiri, sehingga bentuknya tidak semata prosesi upacara dan pertarungan ayam, tetapi bentuk lainnya yang lebih banyak menyiratkan kritik sosial pada aktivitas tersebut.

Dengan berlandaskan gagasan dari berbagai pengalaman dalam melakukan aktivitas adat dan agama, terutama pemyimpangan dalam pelaksanaan upacara dan judi, melahirkan sebuah konsep penciptaan yaitu karya seni rupa yang mengandung kritik sosial dan nilai-nilai moral, etika, prilaku, kebajikan. Swadharma sebagai umat manusia yang hidup dalam lingkungan sosial masyarakat yang menjunjung tinggi nilai kebersamaan diharapkan dapat melahirkan karya yang berlandaskan pada ajaran Sanatana Dharma yaitu: Satyam, Çiwam, Sundharam untuk mencapai keseimbangan dan keharmonisan. Satyam adalah menegakkan kebenaran, Çiwam menegakkan kesucian, dan Sundharam menegakkan keharmonisan dan keindahan (Wiana, 2004: 14).

Karya yang diciptakan adalah karya seni rupa yaitu lukis, patung, kriya, dan instalasi. Karya seni rupa yang selama ini masih dikotak-kotakan berdasarkan material, teknik, gaya, fungsi yang berakibat pada sempitnya ruang kreativitas, telah lebur dan luluh seakan antara yang satu dengan yang lainnya telah menjadi satu yaitu seni rupa. Karya ini diharapkan dapat menjawab esensi penciptaan, bahwa semua seni rupa sarat dengan ekspresi, ide, gagasan, dan ketrampilan sehingga karya yang dilahirkan memiliki jiwa, roh, dan nilai yang sangat dalam dengan bentuk yang khas, unik dan partikular.

Keunikan karya dimunculkan dari konsep karya, pengolahan bentuk, kolaborasi berbagai material yang ada, pemanfaatan teknik kerja yang bebas dan ekspresi, dan penampilan karya. Bahan akan mempunyai peranan penting dalam melahirkan bentuk, karena kemunculan ide beberapa karya terinspirasi dari bahan yang digunakan. Ide bentuk terlahir setelah berkomunikasi dengan material yang ada.

Karya yang ditampilkan berwujud dua dan tiga dimensional sesuai dengan ide pencipta serta material yang digunakan. Media yang digunakan lebih banyak dari kayu dikombinasikan dengan material lain seperti kanvas, logam, tempurung, rotan dan sebagainya. Penciptaan karya ini berorientasi pada karya seni murni yaitu karya yang lebih menekankan pada nilai seni itu sendiri yang sarat dengan teks dan konteks.

Ukuran karya dalam penciptaan ini sangat bervariasi sesuai dengan ide dan gagasan pencipta. Beberapa karya dalam satu judul terdiri dari beberapa karya, sehingga ukurannya menjadi variabel. Teknik pengerjaan yang digunakan adalah teknik pahatan, konstruksi, lukis, sungging, kolase, dan kenteng. Teknik pahatan adalah teknik konvensional dalam penciptaan karya kriya, namun dalam penciptaan ini teknik pahatan dilakukan dengan ekspresif sehingga kekuatan keterampilan dan ekspresif akan menyatu. Teknik pahatan banyak digunakan dalam karya yang menggunakan bahan kayu baik dalam bentuk patung maupun relief. Teknik konstruksi digunakan untuk menyambung beberapa kayu menjadi lebih besar atau panjang. Teknik konstruksi dapat memberi kebebasan dalam membuat bentuk yang bergerak dan dinamis, karena material dapat disambung antara yang satu dengan yang lainnya. Dalam hal ini konstruksi tidak hanya sebagai teknik, tetapi menjadi unggulan dalam penciptaan ini, karena dalam penciptaan karya yang besar tidak mesti menggunakan material yang besar, tetapi dapat dikonstruksi. Teknik kenteng digunakan untuk mengolah lempengan logam untuk mendapatkan tekstur logam yang artistik. Teknik kenteng juga akan digunakan untuk membuat motif hias yang diterapkan pada logam.

Untuk karya seni lukis akan lebih banyak mengkombinasikan antara teknik modern dengan teknik tradisional. Perpaduan teknik ini akan menghasilkan karya yang baru yaitu komnbinasi antara ekspresi dengan dekoratif. Karakteristik karya banyak dimunculkan dengan teknik tradisional, dengan bentuk-bentuk yang galak, sangar, dan menyeramkan. Ekspresi dimunculkan dengan sapuan warna yang bebas, tetapi terukur. Teknik sungging juga dimunculkan dalam karya seni lukis dengan memberi warna gradasi dari warna gelap ke terang atau sebaliknya.

Penciptaan ini merupakan karya original cerminan identitas individu sebagai seorang seniman yang kreatif dan inovatif. Karya seni original adalah karya seni dengan proses kreatif yang melibatkan perenungan secara mendalam serta menghindari peniruan. Sebuah karya seni dianggap original jika pokok persoalannya, bentuk dan gaya yang ditampilkan adalah baru (Sumartono, 1992: 2). Originalitas dalam karya ini adalah tidak meniru karya yang telah 
ada, tetapi menciptakan sesuatu yang baru yang bersumber pada fenomena ritual Hindu dan Judi tajen yang ada di Bali dengan mengadakan berbagai pengolahan, baik bentuk, teknis, gaya, sehingga menjadi sebuah karya kriya yang memiliki identitas sendiri.

Penciptaan ini direpresentasikan dalam karya dekoratif dan figuratif yang penekannannya lebih pada pencapaian tujuan dan sasaran karya. Karya dekoratif dan figuratif dapat memberi daya tarik sendiri pada masyarakat untuk menikmati dan mudah dapat dipahami secara visual maupun kandungan isinya. Karya ini diharapkan dapat memberikan pesan moral pada masyarakat untuk introspeksi diri tentang kesalahan yang telah dilakukan selama ini.

\section{SIMPULAN}

Pelaksanaan upacara yadnya selalu dilaksanakan dengan tampilan yang besar, mewah, meriah, elegan, labih mengutamakan seremonial dari pada nilai religiusnya. Nilai sebuah upacara selalu dilihat dari kemewahan dan semaraknya pelaksanaan, bukan dari isi dan esensi religius. Budaya ini dianggap suatu yang wajar oleh masyarakat dan wajib untuk dilaksanakan. Yang lebih memprihatinkan adalah aktivitas upacara yadnya selalu diikuti dengan berbagai judian dan dilaksanakan di areal suci. Upacara yadnya sering dijadikan tameng untuk melaksanakan judi agar aman dan nyaman. Tidak jarang dalam aktivitas upacara masyarakat dengan sengaja melaksanakan judi untuk penggalian dana agar dapat meminimalis iuran.

Berbagai elemen estestis terdapat dalam pelaksanaan upacara yadnya, tidak saja sarana upakaranya, tetapi juga segala aktivitasnya. Elemen estetis tersebut merupakan kekayaan sumber ide untuk ditranformasikan dalam penciptaan karya seni rupa yang unik dan menarik yang dapat dituangkan pada berbagai media yang beragam dalam bentuk yang bervariasi. Kreativitas dan inovasi pencipta akan tertuang secara total untuk melahirkan karya seni yang memiliki karakteristik sebagai identitas garapan.

Penciptaan karya tidak semata memunculkan nilai estetika visual belaka, tetapi juga tersirat berbagai nilai kebajikan dan pendidikan, terutama yang berkaitan dengan kesalahan dalam pelaksanaan ritual yang selalu dibarengi dengan judi. Visual karya akan mencerminkan beberapa penyimpangan upacara yadnya, sehingga masyarakat akan memahami bahwa pelaksanaan upacara yang selama ini dilakukan masih banyak yang perlu disempurnakan.

\section{DAFTAR RUJUKAN}

Atmadja, Nengah Bawa, Tajen di Bali; Perspektif Homo Cmplexus, Pustaka Larasan IBBi KUndiksha, Singaraja, 2015.
Daksa, Acarya Paramananda Muni, Kesalahpahaman Dibalik Yadnya Mecaru di Bali, CV. Bali Media Adhikarsa, Denpasar, 2008.

Djendra, Ida Bagus Rai, Hindu Agama Universal, Paramita, Surabaya, 2013.

Kerepun, Kembar Made, Kelemahan dan Kekuatan Manusia Bali (Sebuah Otokritik), PT. Empat Warna Komunikasi, Denpasar, 2007.

Mertha, I Ketut, Politik Kriminal: Dalam Penanggulangan Tajen di Bali, Udayana University Press, Denpasar, 2010.

Purwita, Ida Bagus Putu, Pengertian Tabuh Rah di Bali, Pemda Bali, Denpasar,2003

Putrawan, I Nyoman, Ceki Puja Menipu Diri Dengan Dalih Agama, Pustaka Bali Post, Denpasar, 2004.

Setia, Putu, Menggugat Bali, Pustaka Grafiti perss, 1986.

Subawa, I Gede, Reformasi Retual, Mentradisikan Agama Bukan Mengagamakan

Sugiarto, Bambang, Agus Rahmat W., Wajah Baru Agama dan Etika, Kanisius, Yogyakarta, 2000.

Tradisi, Pustaka Bali Post, 2012.

Triguna, Ida Bagus Gde Yudha, Editor, Estetika Hindu dan Pembangunan Bali, Widya Dharma, Denpasar, 2003.

Utarayana, Pengayam-Ayam, Offset Ria, Denpasar, 1993.

Wiana, I Ketut, Mengapa Bali Disebut Bali?, Paramita, Surabaya, 2004.

" Ajeg Bali adalah Tegaknya Kebudayaan Hindu Bali”, Dialog Ajeg Bali, Paramita, Surabaya, 2005.

Wijayananda, Ida Pandita Mpu Jaya, Makna Filosofis Upacara dan Upakara, Paramita, Surabaya, 2004. 